$\mathrm{DOI}$

\title{
ФАКТОРИ РИЗИКУ ЗНИЖЕННЯ ЗАХИСНИХ МЕХАНІЗМІВ ДИХАЛЬНИХ ШЛЯХІВ У ПІДЛІТКІВ
}

\author{
ФЛ. Ф. Матюха, О. Б. Тиш, Т. М. Бухановська \\ Національна медична академя післядипломної освіти імені П. Л. Шупика
}

РЕЗЮМЕ. У статті відображено збільшення частоти захворювань дихальних шляхів протягом одного року у дітей підліткового віку, які перебувають під впливом тютюнового диму. Встановлено, що підлітки-курці та пасивні курці частіше хворіють, і це залежить від ступеня навантаження підлітків тютюновим димом. Отримані дані свідчать про необхідність розробки профілактичних заходів, спрямованих на зменшення наслідків впливу тютюнового диму.

КЛЮчОВІ СЛОВА: діти підліткового віку, захворюваність, захворювання дихальних шляхів, курці, пасивне куріння.

Вступ. Згідно з даними Всесвітньої організації охорони здоров'я (ВООЗ), майже половина всіх дітей страждає від тютюнового диму, в основному через куріння батьків та інших членів сім'ї.

Тютюнопаління - лідер з усіх причин смерті, яким можна запобігти. Відомо, що кожні шість секунд від тютюнозалежних хвороб у світі помирає одна людина [1]. Якщо не вживати ефективних заходів, протягом цього століття від тютюну загине 1 млрд людей [1-3]. Тютюнопаління стає причиною смерті близько 120 тис. українців щорічно. До того $ж$, це фактор ризику більше ніж 25 хворо6, що складає 75 \% структури смертності населення. Отже, тютюнопаління несе величезні економічні збитки як для окремої сім'ї, так і для держави загалом .

Можна з впевненістю сказати, що за рахунок втілення заходів контролю Україна досягла певних успіхів у зниженні поширеності куріння. Частка щоденних курців серед дорослого населення загалом знизилася з $37 \%$ у 2008 р. до $25 \%$ у 2010 р. [5]. Соціальна поведінка, життєві установки, стереотипи поведінки людини закладаються в дитинстві. Доведено, що 80 \% дорослих курців починають палити у віці до 18 років. Тому особливо важливо дослідити поширеність тютюнопаління серед учнів підліткового віку, які $\epsilon$ групою ризику щодо залучення до даної шкідливої звички. Найчастіше в підлітковому віці виникають передумови для формування нікотинової залежності в майбутньому, тютюнопаління $\epsilon$ емпіричним індикатором девіантної (ризикованої) поведінки, яка часто поєднується згодом з вживанням алкоголю, а іноді - і наркотичних речовин [6].

Особливо небезпечним джерелом $€$ материнське куріння, яке негативно впливає на здоров'я дитини під час вагітності та у перші місяці після пологів, коли мати постійно перебуває поруч із дитиною [5].
Дослідження показали, що ймовірність захворювань дихальних шляхів у дітей (спричинених курінням матері) в 1,7 раза вища, ніж у дітей, чиї матері не курять. Куріння батька збільшує ризик захворювань дихальної системи в 1,3 раза [4].

У сім'ях, де діти перебували в одному приміщенні з курцями, вони удвічі частіше хворіли на респіраторні захворювання, порівняно з дітьми, батьки яких курили в окремому приміщенні, або з дітьми, батьки яких взагалі не курили [7].

Загальновідомо, що пасивне куріння у дітей викликає захворювання на бронхіт, пневмонію, напади астми, запалення середнього вуха, завдаючи істотної шкоди здоров'ю населення та призводячи, по суті, до таких же потологічних проявів, як активне куріння.

Мета дослідження: дослідити частоту захворюваності дихальних шляхів у осіб підліткового віку залежно від навантаження тютюновим димом.

Матеріал і методи дослідження. За період 3 березня по травень 2015 р. ми провели обстеження 238 школярів віком від 12 до 16 років, які проживають в сільській місцевості. Усім школярам проводили анкетування, пульсоксиметрію та пробу Руф'є. Дослідження повністю було забезпечене конфіденційністю інформації про респондентів: використовували спеціально розроблену анонімну анкету, участь у дослідженні була добровільна, погоджена із батьками. Заповнення анкети відбувалося після короткого інструктажу про мету дослідження. У групи обстежуваних було включено учнів старших класів (1998-2003 р.н.).

В подальшому у дослідження було включено 185 дітей, оскільки на етапі проведення аналізу не брали до уваги 53 анкети через їх некоректне заповнення. Анкета включала запитання щодо контактів підлітків з тютюновим димом, зокрема, чи курять вони самі, їхні батьки, як часто вони хворіли на захворювання бронхолегеневої системи впродовж останнього року, як часто застосо- 
Огляди літератури, оригінальні дослідження, погляд на проблему вували антибактеріальну терапію, чи переносили хірургічні втручання з приводу захворювань ЛОРорганів. З'ясовували також наявність спадкового анамнезу щодо захворювань бронхолегеневої

системи. Статистичну обробку результатів проводили з використанням стандартних пакетів програм Microsoft Excel®. Дані про респондентів наведені в таблиці 1.

Таблиця 1. Характеристика респондентів-підлітків

\begin{tabular}{|l|c|c|}
\hline \multicolumn{1}{|c|}{ Показник } & Абс. число & $\% \pm \Delta \%$ \\
\hline Підлітки чоловічої статі & 96 & $51,9 \pm 3,6$ \\
\hline Підлітки жіночої статі & 89 & $48,1 \pm 3,7$ \\
\hline Підлітки-курці & 25 & $13.5 \pm 2,5$ \\
\hline Обоє батьків курять & 24 & $13,0 \pm 2,5$ \\
\hline Один з батьків курить & 54 & $29,2 \pm 3,3$ \\
\hline Ніхто в сім'ї не курить & 82 & $44,3 \pm 3,6$ \\
\hline
\end{tabular}

У дослідженні взяли участь $96((51,9 \pm 3,6) \%)$ підлітків чоловічої статі та $89((48,1 \pm 3,7) \%)$ - жіночої. Залежно від ступеня контакту з тютюновим димом школярів поділили на 4 групи. Найбільшу частку склали діти, які не курять самі та не курять їх батьки, вони увійшли до контрольної групи. Ця група включала $82((44,3 \pm 3,6) \%)$ особи. Перша група - підлітки, які не курять, але у яких курить один з батьків - $54((29,2 \pm 3,3) \%)$ особи. Друга група - підлітки які не курять, але у яких

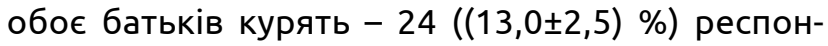
денти. Третя група - підлітки, які самі курять $25((13,5 \% \pm 2,5) \%)$ осіб. Ця група сформована не лише за результатами анкетування, при якому 6 підлітків дали стверджувальну відповідь щодо факту куріння, а і за допомогою тесту на виявлення котініну імунохроматографічним експресметодом в сечі опитуваних, що дало змогу підтвердити факт куріння серед 19 підлітків. Після додаткового анкетування цієї групи з'ясовано, що стаж куріння в групі становив від одного до чотирьох років.

Результати й обговорення. Для досягнення зазначеної мети досліджено, як респонденти самі оцінюють частоту випадків захворювань дихальних шляхів за останній рік (табл. 2).

Таблиця 2. Оцінка респондентами частоти захворювань дихальних шляхів

\begin{tabular}{|l|c|c|c|c|c|c|}
\hline \multirow{2}{*}{ Показник } & \multicolumn{2}{|c|}{ Не хворіли впродовж року } & \multicolumn{2}{|c|}{ Хворіли 1 раз на рік } & \multicolumn{2}{c|}{ Хворіли 2-3 рази на рік } \\
\cline { 2 - 7 } & абс. число & $\% \pm \Delta \%$ & абс. число & $\% \pm \Delta \%$ & абс. число & $\% \pm \Delta \%$ \\
\hline Контрольна група & 27 & $(32,9 \pm 5,2)$ & 42 & $(51,2 \pm 5,5)$ & 13 & $(15,9 \pm 4,0)$ \\
\hline I група & 13 & $(24,0 \pm 5,8)$ & 24 & $(44,4 \pm 6,8)$ & 18 & $(33,3 \pm 6,4)^{*}$ \\
\hline II група & 7 & $(29,2 \pm 9,3)$ & 8 & $(33,3 \pm 9,6)^{*}$ & 9 & $(37,5 \pm 9,8)^{*}$ \\
\hline III група & 7 & $(28,0 \pm 8,9)$ & 8 & $(32,0 \pm 9,3)^{*}$ & 10 & $(40,0 \pm 9,8)^{*}$ \\
\hline
\end{tabular}

Примітка. * - різниця достовірна відносно показників КГ, p<0,05.

Відповідно до отриманих даних, серед підлітків контрольноїгрупи було $27((32,9 \pm 5,2) \%)$ осіб, які не хворіли за останній рік жодного разу, серед рес-

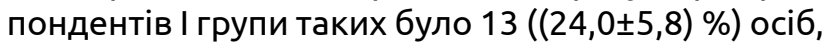

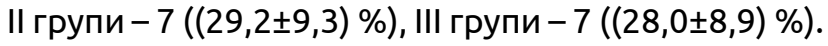
Один випадок захворюваності протягом року в контрольній групі відмітили $42((51,2 \pm 5,5) \%)$ під-

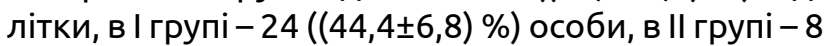
$((33,3 \pm 9,6) \%)$ опитаних, в III групі - $8((32,0 \pm 9,3) \%)$ дітей. На два - чотири випадки захворюваності протягом року вказали в контрольній групі 13 $((15,9 \pm 4,0) \%)$, в I групі - $18((33,3 \pm 6,4) \%)$, в II групі - $9((37,5 \pm 9,8) \%)$, в III групі - $10((40,0 \pm 9,8) \%)$ підлітків. Рівень частоти захворювань дихальних шляхів був достовірно вищий у II та III групах підлітків і складав 37,5 і 40,0 \% відповідно; у підлітків контрольної групи - 15,9\%; $р<0,05$.

Наступним кроком дослідження стало визначення сатурації крові обстежуваних осіб за допомогою пульсоксиметра. Оцінка насичення крові киснем визначалася при значеннях $\mathrm{SpO}_{2} \geq 96 \%$, та $\mathrm{SpO}_{2} \leq 95 \%$ (табл. 3).

За результатами проведеного дослідження сатурації крові (табл. 3) визначено: $\mathrm{SpO}_{2} \geq 96 \%$ в контрольній групі $68(82,9 \pm 14,2) \%)$, в I групі 44

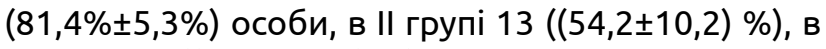
III групі $13((52,0 \pm 10,0) \%) ; \mathrm{SpO}_{2} \leq 95 \%$ в контрольні групі $14((17,1 \pm 4,2) \%)$, в I групі $10((18,5 \pm 5,2) \%)$ 
Огляди літератури, оригінальні дослідження, погляд на проблему

Таблиця 3. Сатурація крові у респондентів-підлітків

\begin{tabular}{|l|c|c|c|c|}
\hline \multirow{2}{*}{\multicolumn{1}{|c|}{ Показник }} & \multicolumn{2}{c|}{$\mathrm{SpO}_{2} \geq 96 \%$} & \multicolumn{2}{c|}{$\mathrm{SpO}_{2} \leq 95 \%$} \\
\cline { 2 - 5 } & абс. число & $\% \pm \Delta \%$ & абс. число & $(17,1 \pm 4,2)$ \\
\hline Контрольна група & 68 & $(82,9 \pm 14,2)$ & 14 & $(18,5 \pm 5,2)$ \\
\hline I група & 44 & $(81,4 \pm 5,3)$ & 10 & $(45,8 \pm 10,1)^{*}$ \\
\hline II група & 13 & $(54,2 \pm 10,2)^{*}$ & 11 & $(48,0 \pm 10,0)^{*}$ \\
\hline III група & 13 & $(52,0 \pm 10,0)^{*}$ & 12 & \\
\hline
\end{tabular}

Примітка. * - різниця достовірна відносно показників контрольної групи, p<0,05.

осі6, в II групі $11((45,8 \pm 10,1) \%)$, в III групі 12 $((48,0 \pm 10,0) \%)$. Значення показників SpO2 $\leq 95 \%$ зростають із зростанням інтенсивності навантаження тютюновим димом підлітків: у контрольній групі - $(17,1 \pm 4,2) \%$, в I групі - $(18,5 \pm 5,2) \%$ що $\epsilon$ недостовірно сутєвою різницею, а вже у II групі $(45,8 \pm 10,1)$ \% і в III групі - $(48,0 \pm 10,0) \%$, що достовірно вище, порівняно з показником контрольної групи; $\mathrm{p}<0,05$.

Для визначення стану серцево-судинної системи підлітків ми провели пробу Руф'є. При ї̈ проведенні підліток, якого обстежували, перебував протягом 5 хвилин у положенні сидячи на стільці, у нього вимірювали частоту пульсу за 15 секунд (P1). Далі підліток робив 30 присідань протягом 45 секунд, знову сідав на стілець, і у перші 15 секунд відпочинку рахували частоту пульсу (показ- ник P2). Рахували частоту пульсу також за останні 15 секунд першої хвилини відпочинку (показник Р3). Формула для оцінки працездатності, тобто індексу Ру $\phi ' \epsilon, \epsilon$ наступною:

$$
(4 \times(P 1+P 2+P 3)-200) / 10 .
$$

Результат оцінювали за шкалою від 0 до 20. Високою працездатність вважали при показнику менше 3. Добра працездатність відповідає результату в межах 4-6. Індекс 7-9 - це показник середньої працездатності. Індекс 10-14 - задовільна працездатність, або ж середня серцева недостатність. Про сильну серцеву недостатність сигналізує індекс 15 та вище. Отримані результати поділили на дві групи: від 0 до 10 та від 10,1 до 20. Отримані дані після проведеної проби Руф'є респондентів-підлітків усіх груп наведено в таблиці 4.

Таблиця 4. Проба Руф'є респондентів-підлітків

\begin{tabular}{|l|c|c|c|c|}
\hline \multirow{2}{*}{ Показник } & \multicolumn{2}{|c|}{ Від 0 до 10} & \multicolumn{2}{c|}{ Від 10,1 до 20 } \\
\cline { 2 - 5 } & абс. число & $\% \pm \Delta \%$ & абс. число & $\% \pm \Delta \%$ \\
\hline Контрольна група & 72 & $(87,8 \% \pm 3,6 \%)$ & 10 & $(12,2 \% \pm 3,6 \%)$ \\
\hline I група & 39 & $(72,2 \% \pm 6,1 \%)$ & 15 & $(27,8 \% \pm 6,1 \%)$ \\
\hline II група & 12 & $(50,0 \% \pm 10,2 \%)^{*}$ & 12 & $(50,0 \% \pm 10,2 \%)^{*}$ \\
\hline III група & 12 & $(48,0 \% \pm 10,0 \%)^{*}$ & 13 & $(52,0 \% \pm 10,0 \%)^{*}$ \\
\hline
\end{tabular}

Примітка. * - різниця достовірна відносно показників КГ, p<0,05.

Визначено: проба Руф'є від 0 до 10 в контрольній групі була у $72((87,8 \pm 3,6) \%)$ підлітків, в I групі - у $39((72,2 \pm 6,1) \%)$, в II групі - у 12

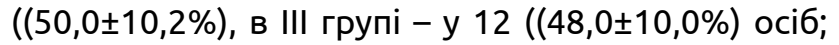
показники від 10,1 до 20 в контрольній групі мали $10(12,2 \pm 3,6) \%)$ підлітків, в І групі - $15((27,8 \pm 6,1) \%)$ осі6, в II групі - $12((50,0 \pm 10,2) \%)$ в ІІІ групі - 13 $((52,0 \pm 10,0) \%)$ підлітків. Спостерігали достовірне зменшення питомої ваги проби Руф'є від 0 до 10 в II та III групах: $(50,0 \pm 10,2) \%$ та $(48,0 \pm 10,0) \%$ відповідно до $(87,8 \pm 3,6) \%$ контрольної групи; $\mathbf{p}<0,05$. Разом з тим, збільшились незадовільні показники від 10,1 до 20 в II та III групах: $(50,0 \pm 10,2) \%$ та $(48,0 \pm 10,0) \%$ відповідно до $(12,2 \pm 3,6) \%$ контрольної групи $(p<0,05)$.
Висновки. У ході проведеного дослідження встановлено, що із зростанням інтенсивності контакту з тютюновим димом зростає частота захворюваності підлітків на хвороби органів дихання, яка в досліджуваних групах була достовірно вищою у II та III групах підлітків і становила 37,5 \% і 40,0 \% порівняно з підлітками контрольної групи $(p<0,05)$.

Сатурація крові $\mathrm{SpO}_{2} \leq 95 \%$ спостерігалась у $(45,8 \pm 10,1) \%$ респондентів-підлітків II групи - і у $(48,0 \pm 10,0) \%$ III групи - що було достовірно нижчим, ніж у контрольній групі $(p<0,05)$. Незадовільні показники проби Руф'є також були більшими в II та III групах.

Зважаючи на отримані дані, підлітки-курці, пасивні курці потребують особливої уваги з боку 
Огляди літератури, оригінальні дослідження, погляд на проблему

лікарів первинної ланки медичної допомоги і їх необхідно об'єднувати в окрему групу для інформування, спостереження та розробки профілак- тичних заходів, спрямованих на зменшення наслідків впливу тютюнового диму.

\section{ЛІТЕРАТУРА}

1. Доценко Н. Я. Исследование функции внешнего дыхания в практике семейного врача / Н. Я. Доценко // Укр. мед. вісник «Тherapia» - 2015. - № 1 (94). - С. 9-12.

2. Крамарев С. А. Дифференцированный подход к лечению кашля / С. А. Крамарев // Здоровье ребенка. 2013. - № 6 (49). - С. 100-104.

3. Сучасні методи профілактики та лікування тютюнової залежності в практиці сімейного лікаря / Д. Д. Дячук, Т. С. Грузєва, Г.В.Іншакова [та ін.] // Главный врач. -2014. - № 12. - С. 28-31.

4. Жигунова А. К. Острые респираторные инфекции: основные проявления, механизмы развития, симпто- матическая и патогенетическая терапия / А. К. Жигунова // Сімейна медицина. - 2015. - № 1. -С. 45-52.

5. Чергінець В. І. Можливості захисту дихальної системи дітей від негативного впливу пасивного тютюнопаління / В. І. Чергінець, Н. С. Башкірова, С. П. Дігтяр // Здоровье ребенка. - 2010. - № 5 (26). - С. 45-46.

6. Preventing Tobacco Use among Youth and Young Adults / Executive Summary / U.S. Department of Health and Human Services. - 2012. - 11 p.

7. Грузєва О. В. Сучасна інформаційно-освітня програма профілактики куріння серед підлітків / О. В. Грузєва // Український наук.-мед. молодіжний журнал. 2010. - № 1. - С. 20-27.

\section{RISK FACTORS OF REDUCING THE PROTECTIVE MECHANISMS OF RESPIRATORY TRACTS IN ADOLESCENTS}

@L. F. Matiukha, O. B. Tysh, T. M. Bukhanovska

\section{P. L. Shupyk National Medical Academy of Postgraduate Education}

SUMMARY. The article shows the increased frequency of respiratory diseases for one year in adolescents who are under the influence of tobacco smoke. It was found out that adolescents smokers and passive smokers get sick more often, depending on the load for adolescents with tobacco smoke. These data suggest the need to develop preventive measures to reduce the effects of tobacco smoke.

KEY WORDS: adolescents, morbidity, respiratory tracts diseases, smokers, passive smoking. 